\title{
A new model system for endometritis in mares - preliminary results
}

\author{
F. Engelke', H. Zerbe' ${ }^{2}$, E. Klug ${ }^{3}$ and W. Leibold \\ ${ }^{1}$ Immunology Unit, ${ }^{2}$ Clinic for Bovine Gynecology and Obstetrics and ${ }^{3}$ Clinic for Horses, School of Veterinary Medicine Hannover, Hannover, BRD
}

\begin{abstract}
Summary
In the framework of establishing a defined model system of acute endometritis in mares, we studied the immigration of polymorphonuclear neutrophil granulocytes (PMN) into the uterus and compared their properties with those of contemporarily harvested PMN from peripheral blood (blood PMN). Based on preliminary in-vitro-studies, we used intrauterine infusion of recombinant human interleukin 8 (rhlL-8) as a well defined and physiological inductor of PMN migration into the mares uterus. Before, 3,6 and $24 \mathrm{~h}$ after the infusion, cells were flushed from the uterine lumen. In addition to total leukocyte counts, viability and morphological differentiation of various leukocyte populations and phenotypic characteristics were monitored using monoclonal antibodies. The capacity of PMN to generate reactive oxygen species (ROS) after stimulation with phorbol ester was determined using dihydrorhodamine (DHR) 123 as indicator. The phagocytic activity of PMN was measured by their ingestion of fluorochrome labelled nonviable streptococci. Viability, phenotype, ROS-generation and phagocytosis were evaluated by means of flow cytometry. Preliminary results of our investigations document large numbers of luminal PMN $\left(1.8\right.$ to $\left.78 \times 10^{7}\right)$ upon intrauterine rhlL-8-infusion ( $n=7)$. More than $98 \%$ of the recovered cells were PMN with a viability of 90 to $99 \%$ when harvested $6 \mathrm{~h}$ post rhIL-8-application. In comparison with contemporarily harvested autologous blood PMN, uterine neutrophils showed significant changes in the expression of some of their surface molecules. While ROS-generation by uterine PMN was increased, their phagocytic activity was not significantly different from that of autologous blood PMN.
\end{abstract}

Keywords: $\quad$ mare, endometritis, PMN, interleukin 8

\section{Vorläufige Ergebnisse zur Entwicklung eines Endometritismodells für die Stute}

Ziel der Untersuchungen war es, ein Endometritismodell für die Stute zu erstellen. Als erster Schritt dazu sollten gezielt polymorphkernige neutrophile Granulozyten (PMN) in den Uterus gelockt und auf ihre Eigenschaften untersucht werden. PMN sind von entscheidender Bedeutung für die Aufrechterhaltung der endometrialen Gesundheit. Um die Granulozyteneinwanderung in den Uterus unter möglichst physiologischen Bedingungen zu stimulieren, wurde rekombinantes humanes Interleukin 8 (rhlL-8) eingesetzt. Sowohl vor als auch 3, 6 und 24 Stunden nach der intrauterinen rhIL-8-Applikation wurden Uterusspülungen vorgenommen. Neben einer Zellzählung, Vitalitätsprüfung und morphologischer Differenzierung der gewonnenen Leukozyten wurde eine Phänotypisierung mittels Membranimmunfluoreszenz (MIF) mit monoklonalen Antikörpern spezifisch für unterschiedliche Zelloberflächenstrukturen durchgeführt. Funktionell wurde die Kapazität zur Bildung reaktiver Sauerstoffspezies (ROS) nach Stimulierung durch Phorbolester unter Verwendung von Dihydrorhodamin (DHR) 123 untersucht und die Phagozytoseaktivität der gewonnenen PMN mittels Ingestion fluorochrommarkierter Streptokokken überprüft. Vitalität, Immunphänotyp, ROS-Bildung und Phagozytoseaktivität wurden durchflußzytometrisch ausgewertet. Als vorläufiges Ergebnis unserer Untersuchungen ( $n=7$ ) ist festzuhalten, daß durch die intrauterine Infusion von rhIL-8 ein starker Einstrom von Leukozyten in das Uteruslumen induziert wurde $(1,8$ bis $78 \times 10^{7}$ ). Der Anteil neutrophiler Granulozyten betrug mehr als 98\%, von denen nach 3 und 6 Stunden 90-99\% als membranintakt identifiziert wurden. Nach 24 Stunden fiel diese Quote deutlich geringer aus. Im Vergleich mit gleichzeitig gewonnenen autologen Blutgranulozyten wurden deutliche Expressionsveränderungen einiger Oberflächenmoleküle auf uterinen PMN festgestellt. Funktionell wiesen uterine PMN eine stärkere ROS-Bildung auf als periphere Blut-PMN. Die Phagozytoseaktivität uteriner PMN unterschied sich nicht signifikant von der der Blut-PMN.

Schlüsselwörter: Stute, Endometritis, PMN, Interleukin 8

\section{Introduction}

Acute endometritis in the mare is a natural consequence of opportunistic microbial infection of the uterus during mating regardless of how clean the procedure is. Bacterial infection usually resolves within few hours or days (Evans et al. 1986; Watson 1988), and the uterus remains free of infection before the embryo enters the uterine cavity. Some mares are susceptible to persistent endometritis with chronic inflammation, which can result in degenerative changes and reduced fertility (Hughes and Loy, 1969; Kenney, 1978). It has been suggested that inability to spontaneously eliminate bacterial infection from the uterus is associated with an impaired local uterine immune response.
During acute endometritis, large numbers of polymorphonuclear neutrophils (PMN) migrate into the uterine lumen (Peterson et al., 1969; Watson 1988).

In earlier studies, uterine PMN of susceptible mares have shown a dysfunction to migrate, phagocytize and kill ingested material compared to resistant mares (Asbury et al., 1982; Cheung et al., 1985; Liu et al., 1985). In contrast, Asbury and Hansen (1987) found that the phagocytic capacity of uterine PMN collected $4 \mathrm{~h}$ after infection was greater for susceptible than for resistant mares if given the right environment. In conclusion, insufficient complement in uterine secretions and impaired opsonization were suggested to be 
responsible for a lower phagocytic activity of uterine PMN (Troedsson et al., 1993), although increased amount of immunoglobulin has been found in uterine washings of susceptible mares (Asbury et al., 1980; Mitchell et al., 1982).

Mattos et al. (1997) observed improved pregnancy rates after postbreeding intrauterine infusion of plasma and leukocytes. Intrauterine infusion of autologous plasma with leukocytes was also described as effective method to eliminate bacterial infection: less days were needed for bacterial elimination than with intrauterine infusion of plasma alone (Castilho et al., 1994).

However, the effect of neutrophil functional abilities on susceptibility to endometritis remains unclear. In their studies on puerperal endometritis in cows, Zerbe et al. (1996) demonstrated that uterine PMN of genitally healthy cows showed changes in the expression of some of their surface structures and a significant lower phagocytic activity compared to blood PMN.

In order to develop effective therapeutic approaches, it is necessary to understand the functional properties of uterine PMN and their regulation. Therefore, we have started to develop a model for equine endometritis by studying the migration kinetics of peripheral blood cells into the uterus and to monitor some of their functional and phenotypical properties.

\section{Materials and methods}

\section{Animals}

Seven healthy mares aging between 3 and 12 years were used for this study. Before infusion of recombinant human interleukin-8 (rhlL-8), the mares were submitted to gynecological examination including rectal palpation, vaginoscopy and bacteriological examination of uterine flushings (zero flush). The mares were clinically healthy and no bacterial growth was obtained. The mares had grade I uteri, as determined by endometrial biopsies.

\section{Collection and isolation of PMN from peripheral blood}

Venous blood was taken from each mare immediately after flushing the uterus for harvesting the PMN using sodiumheparinized Vacutainers $®$ (Becton Dickinson, Heidelberg, Germany). Following erythrocyte sedimentation, the leukocyte rich supernate was used for separating the PMN on a discontinuous Percoll density gradient (55\% and $78 \%$ of a normotonic stock; Pharmacia, Freiburg, Germany). Following centrifugation ( $1000 \times \mathrm{g}, 25 \mathrm{~min}, 20^{\circ} \mathrm{C}$ ), the harvested neutrophilic granulocytes were washed twice with PBS $\left(100 \times \mathrm{g}, 8 \mathrm{~min}, 4^{\circ} \mathrm{C}\right)$ and resuspended in medium (RPMI 1640 supplemented with $3 \%$ fetal calf serum) to a final concentration of $2 \times 10^{6} \mathrm{PMN} / \mathrm{ml}$.

\section{Collection and isolation of uterine PMN}

A solution of recombinant human interleukin 8 (rhIL-8; BioConcept, Umkirch, Germany) was used as chemoattractant substance. At first, the uterus was flushed with $50 \mathrm{ml}$ of sterile PBS (zero flush) to evaluate the amount and composition of the initial uterine cell harvest and bacteria. Five mares received an infusion of $50 \mathrm{ml}$ PBS with a rhIL-8 concentration of $25 \mathrm{ng} / \mathrm{ml}$, in two mares the concentration was $10 \mathrm{ng} / \mathrm{ml}$. Two mares served as control, they received a PBS infusion without rhlL-8. Three, 6 and $24 \mathrm{~h}$ after rhlL-8 infusion, a Foley catheter was inserted through the cervix. Fifty $\mathrm{ml}$ of sterile PBS were introduced into the uterus after inflating the balloon. Gentle massage of the uterus was performed per rectum, and uterine washings were allowed to flow into sterile polypropylene tubes by gravity. This procedure was repeated with $5 \times 50 \mathrm{ml}$ of PBS. The sample tubes were stored on ice. The cells were washed with PBS and resuspended in medium to a final concentration of $2 \times 10^{6} / \mathrm{ml}$.

Counts, differentiation and viability test of cells

The total leukocyte concentration in uterine washings was determined by counting at least 100 leukocytes in a cell counting chamber after staining with acridine orange (2,5 $\mathrm{\mu g} / \mathrm{ml}$ PBS) by fluorescence microscopy. Differential counts were determined by flow cytometry acquiring 2000 leukocytes per test (FACScanß; Becton Dickinson, Heidelberg, Germany). Cell viability was evaluated by flow cytometry after addition of propidium iodide $(2 \mu \mathrm{g} / \mathrm{ml}$ cell suspension; Calbiochem Novabiochem $\mathrm{GmbH}$, Bad Soden).

\section{Indirect membrane immunofluorescence}

The phenotypic characteristics of PMN were monitored by means of quantitative indirect immunofluorescence using monoclonal antibodies (see Tab. 1). A modified method previously described by Zerbe et al. (1996) was used. Brief-

Tab. 1: List of monoclonal antibodies (mAb) used for phenotypical characterisation.

Für die Phänotypisierung verwendete monoklonale Antikörper.

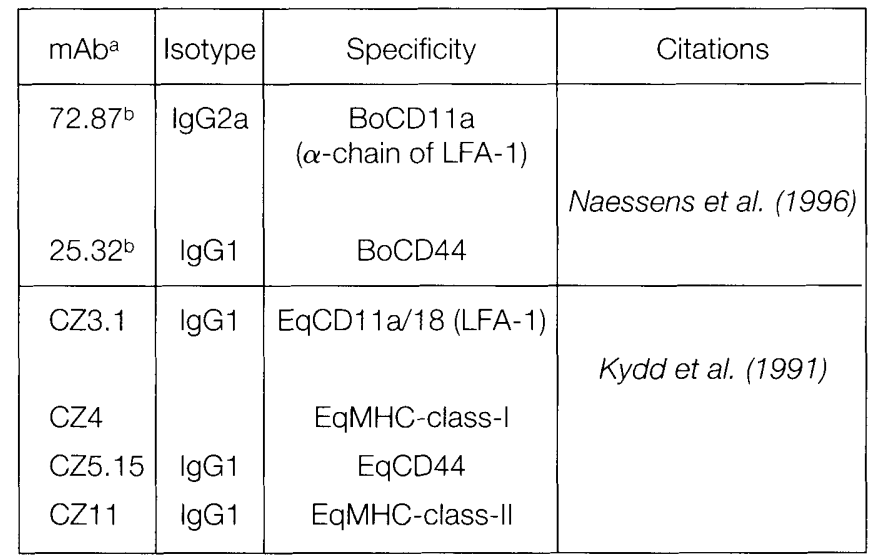

BoCD, Bovine cluster of differentiation;

EqCD, Equine cluster of differentiation;

LFA-1, Lymphocyte function associated antigen 1;

MHC-class-I, -II, Major histocompatibility complex class I, -II.

a Name of hybridoma cell clones and the mAb produced by them.

$b$ Cross reactive antibodies from the workshop on ruminant leukocyte antigens. 
ly, $100 \mu \mathrm{l}$ of cell suspension ( $2 \times 10^{5}$ leukocytes) were incubated with the primary monoclonal antibody (mAb) or PBS as negative control $\left(30 \mathrm{~min}, 4^{\circ} \mathrm{C}\right)$. After two washing steps $\left(220 \times \mathrm{g}, 3 \mathrm{~min}, 4^{\circ} \mathrm{C}\right)$ with assay buffer (PBS supplemented with $0.01 \% \mathrm{NaN}_{3}$ and $1 \%$ bovine serum albumin), $25 \mu \mathrm{l}$ of the secondary fluoresceinisothiocyanat-conjugated antibody (FITC, goat-anti-mouse; Dianova, Hamburg, Germany) were added to the resuspended cell sediment. The cells were incubated in the dark $\left(30 \mathrm{~min}, 4^{\circ} \mathrm{C}\right)$ followed by two washing steps (as above). Finally, the cell sediment was resuspended and $100 \mu$ of PBS were added. Just before flow cytometric analysis, propidium iodide $(2 \mu \mathrm{g} / \mathrm{ml})$ was added to exclude damaged (propidium iodide positive) cells.

\section{Generation of reactive oxygen species (ROS)}

This essay was performed according to the method described by Emmendörffer et al. (1990). The generation of ROS was triggered by addition of phorbol myristate acetate (PMA; Sigma, Deisenhofen, Germany) in final concentrations of 30,100 and $300 \mathrm{nmol} / /$ to $100 \mu \mathrm{l}$ of cell suspension ( $2 \times 10^{5}$ leukocytes in medium). After 15 min of incubation at $37^{\circ} \mathrm{C}$, the nonfluorescent dye Dihydrorhodamin 123 (DHR 123; Molecular Probes, Inc., Eugene, Oregon, USA) was added. It is taken up easily into cells and converted into the green fluorescing rhodamine 123 via oxidation catalyzed by cellular myeloperoxidase. The oxidative transformation of DHR 123 depends on the amount of ROS generated and can be quantified by means of fluorescence intensity.

\section{Phagocytic activity}

The phagocytic activity was determined according to a method previously described by Zerbe et al. (1996). A commercially available nonviable Streptococcus zooepidemicus-suspension (Omnisorbin $\AA$, Calbiochem Novabiochem $\mathrm{GmbH}$, Bad Soden) was labelled with FITC (Sigma, Deisenhofen). This was followed by opsonization of the bacteria with native or complement inactivated $\left(60 \mathrm{~min}, 56^{\circ} \mathrm{C}\right)$ pooled equine serum of healthy individuals or PBS. Upon opsonization, leukocytes and bacteria were mixed in a ratio of 1:100 and incubated for 60 min at $37^{\circ} \mathrm{C}$. In flow cytometric analysis, PMN which ingested FITC-labelled streptococci could be distinguished from non-phagocytic PMN by an increased green fluorescence.

\section{Preliminary results}

The zero flushings of all mares had negative results in bacteriological culture. No leukocytes could be found in 5 mares, in 2 mares less than $1 \times 10^{5}$ leukocytes were found. The total numbers of leukocytes harvested by uterine washings $3 \mathrm{~h}$ after rhlL-8-application varied from $19 \times 10^{6}$ to $100 \times 10^{6}$ (Fig. 1). More than $98 \%$ of the leukocytes were PMN, and about $92.5 \pm 2.3 \%$ of the PMN were viable.

After $6 \mathrm{~h}$, total numbers of $54 \times 10^{6}$ to $786 \times 10^{6}$ leukocytes were found and more than $98 \%$ were $\mathrm{PMN}$ with a viability of $97.8 \pm 1.1 \%$.
In two mares, the $24 \mathrm{~h}$ flushing did show growth of $\mathrm{E}$. coli in bacteriological culture, and large numbers of PMN were found $\left(900 \times 10^{6}\right.$ and $390 \times 10^{6}$, respectively). The bacteriological negative flushings contained $18 \times 10^{6}$ to $83 \times 10^{6}$ leukocytes, more than $98 \%$ were PMNs with a viability of 42-69\%.



hours after PBS-infusion hours after hIL-8-infusion

Fig. 1: Total number of leukocytes derived from the uterus following $6 \mathrm{~h}$ after intrauterine infusion of $50 \mathrm{ml}$ PBS $(n=2)$ and immediatly before, 3, 6 and $24 \mathrm{~h}$ after intrauterine infusion of recombinant human interleukin 8 (rhlL-8) in $50 \mathrm{ml}$ PBS (10 or $25 \mathrm{ng} / \mathrm{ml})(\mathrm{n}=7)$.

Absolute Anzah: der aus dem Uterus gewonnenen Leukozyten $6 \mathrm{Std}$ nach einer intrauterinen Infusion von $50 \mathrm{ml}$ PBS ( $n=2)$ und direkt vor, sowie 3, 6 und 24 Std nach intrauteriner Applikation von rekombinantem humanen Interleukin-8 (rhlL-8) in $50 \mathrm{ml}$ PBS (10 oder $25 \mathrm{ng} / \mathrm{ml})(\mathrm{n}=7)$.

Flushing unprimed control animals $(n=2), 2.7$ and $4.9 \times 10^{6}$ leukocytes could be recovered $6 \mathrm{~h}$ after PBS infusion. The increase in total PMN numbers after hlL-8 application is significant $(p<0.01)$.

\section{Indirect membrane immunofluorescence}

The density of the tested surface molecules of uterine PMN compared to contemporarily harvested blood PMN is shown in Figure 2. The CD11a/18-recognizing mAb CZ3.1 and the cross reactive bovine CD11a/18-recognizing mAb 72.87 showed an up-regulation of these structures on uterine PMN in all cases. Significantly down-regulated were MHCclass-I (mAb CZ4), equine CD44 (mAb CZ5.15) and the surface molecule recognized by the cross reactive $\mathrm{mAb}$ 25.32 (bovine CD44). MHC-class-II-expression (mAb CZ11) was not induced by rhlL-8 triggered PMN migration into the uterus.

\section{Generation of reactive oxygen species}

The mean fluorescence intensity of unstimulated uterine PMN did not differ from autologous blood PMN ( $p>0.1)$. After stimulation with 30 and $100 \mathrm{nmol} / \mathrm{l} \mathrm{PMA}$, the uterine PMN did show an enhanced capacity to generate microbicidal ROS compared to blood PMN ( $p<0.01$ ), (Fig. 3). Stimulated with $300 \mathrm{nmol} / \mathrm{PMA}$, uterine PMN of four individuals showed also an enhanced fluorescence intensity. In 
three mares, the autologous blood PMN generated more ROS than uterine PMN.

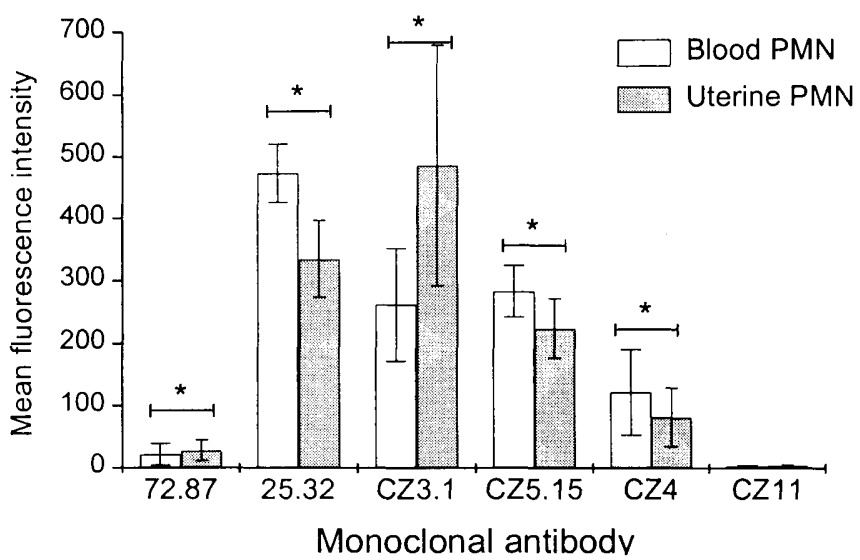

Fig. 2: Expression of surface structures on uterine PMN 6 h after recombinant human interleukin 8 infusion compared to autologous blood PMN $(n=7)$. The values represent the mean fluorescence intensity of propidium iodide negative PMN after labelling with the described mAbs (Tab. 1) and a second fluorochrome conjugated antibody ( $\left.{ }^{*} p<0.01\right)$.

Vergleichende Darstellung der Dichte von Oberflächenmolekülen auf Blut-PMN mit Uterus-PMN $(n=7)$. Die Werte zeigen die mittlere Fluoreszenzintensität der propidiumjodidnegativen PMN nach Markierung mit den aufgelisteten monoklonalen Antikörpern (s. Tab. 1) und einem fluorochrommarkierten Anti-Antikörper ( ${ }^{*} p<0.01$ ).

\section{Phagocytosis}

The phagocytic activity of uterine derived PMN did not differ significantly $(p>0.05)$ from autologous blood PMN after incubation with PBS $(21.4 \pm 1.4 \%$ phagocytic uterine PMN, $18.8 \pm 4.6 \%$ phagocytic blood PMN) and after opsonization with complement inactivated $(28.4 \pm 5.4 \%$ phagocytic uterine PMN, $24.8 \pm 4.1 \%$ phagocytic blood PMN) or native serum $(54.8 \pm 9.2 \%$ phagocytic uterine PMN, $47.0 \pm 9.4 \%$ phagocytic blood PMN).

\section{Discussion}

The purpose of this study was to perform initial steps in establishing a model system of endometritis in mares. This model should allow to analyze different components and mechanisms relevant for the onset and development of this disease. PMN play an important role in the maintenance of endometrial health, and successful attempts to attract equine PMN into the uterine lumen for subsequent analysis have been reported previously. In several studies, a defined amount of Streptococcus zooepidemicus served to induce experimental infection (Liu et al., 1986; Troedsson et al., 1993). Using bacteria for recruiting the PMN might imply that early phagocytic activity might influence subsequent functional assays with these neutrophils. Other workers attracted PMN by means of oysterglycogen Watson et al., 1986). High amounts of uterine PMN could be isolated, but the effect of this substance on in-vitro-functional parameters remains unclear.
An important point was to use a well defined substance for provoking neutrophil migration permitting to study uterine PMN functions under close to physiological conditions. The method to derive an adequate amount of viable PMN from the uterus by means of recombinant human interleukin-8 worked satisfactorily. Our preliminary results indicate that almost up to $8 \times 10^{8}$ cells could be found in uterine flushings.

Varying number of cells retrieved from the uterus might be due to individual or technical differences: In order to avoid mechanical irritation of the endometrium, no persistent cervix block has been used, causing the possible risk of loosing infused rhlL-8. Therefore, further investigations with a smaller volume and varying cytokine concentrations will be needed to achieve more reproducible cell numbers in the uterus.



Fig. 3: Generation of reactive oxygen species of uterine and blood PMN ( $n=7)$. The values represent the means of the green fluorescence intensity (=degree of ROS-generation after stimulation with PMA) of uterine PMN $6 \mathrm{~h}$ after recombinant human interleukin 8 infusion compared with contemporarily harvested autologous blood PMN ( $p<0.01 ;{ }^{\star} p>0.1$ ).

Kapazität von Blut- und Uterus-PMN zur Bildung reaktiver Sauerstoffspezies. Dargestellt sind Mittelwerte der mittleren Fluoreszenzintensität der $\mathrm{PMN}$ als Maß für ihre ROS-Bildung nach Stimulation mit PMA. Verglichen wurden Blut-PMN und 6 Std nach intrauteriner Infusion von rekombinantem humanen Interleukin-8 gewonnene Uterus-PMN $\left({ }^{\star} p<0.01 ;{ }^{\star \star} p>0.1\right)$.

Interestingly, there are significant phenotypical and functional differences between uterine and contemporarily harvested blood PMN: The expression of some surface structures is altered markedly in PMN which had undergone migration into the uterine lumen. For example, in uterine PMN expression of the lymphocyte function associated antigen 1 (LFA-1), detected by the mAb CZ3.1, was significantly upregulated. In contrast, other molecules, such as $\mathrm{MHC}$ class-I and CD44 (detected by the mAbs CZ4 and CZ5.15, respectively) were significantly down-regulated. Previous invitro-studies (data not shown) demonstrated, that these alterations of surface structures appear following moderate activation of PMN, such as incubation with phorbol ester, but not with rhlL-8 concentrations used in these studies.

The capacity to generate ROS has been significantly higher by uterine PMN compared to autologous blood PMN when 
incubated with PMA. Due to the fact that the oxygen metabolism did not differ between uterine and blood PMN when no PMA was added, it is concluded that uterine PMN are not stimulated but primed by their migration into the uterine lumen or their contact with uterine secretions.

The phagocytic activity of uterine PMN did not differ significantly from autologous blood PMN. This is according to previous reports, where a different method was used to detect the phagocytic activity (Cheung et al., 1985).

As observed by Zerbe et al. (1996) in a model system for bovine endometritis, PMN migrated in the uterine lumen showed altered characteristics even in genitally healthy individuals. The differences between blood and uterine PMN might have been caused by rhIL- 8 directly. But an influence of rhiL- 8 in the used concentrations (10 and $25 \mathrm{ng} / \mathrm{ml}$ ) on neutrophil phenotype or generation of ROS could not be detected in vitro (data not shown). The observed alterations of uterine neutrophils might reflect additional influences on PMN during migration into the uterus caused by mediators of other cells than PMN, such as TNF $\alpha$, G-CSF or GM-CSF (Dapino et al., 1994; Whicher and Evans, 1990).

Thus, the concept of inducing endometritis directly by local application of a physiological activator of neutrophil migration such as IL-8 has been successful. This model system of equine endometritis permits analysis of migration of PMN into the uterus under defined conditions. The results indicate that slight differences between uterine and autologous blood PMN can be detected, even in genitally healthy mares. These findings will be used as basic start for subsequent development of this model.

\section{Literature}

Asbury, A. C., Holliwell, R. E. W., Foster, G. W. and Longino, S. J. (1980): Immunoglobulins in uterine secretions of mares with differing resistance to endometritis. Theriogenology 14, 299-308.

Asbury, A. C., Schultz, K. T., Klesius, P. N., Foster, G. W. and Washburn, S. N. (1982): Factors affecting phagocytosis of bacteria by neutrophils in the mares uterus. J. Reprod. Fert. Suppl. 32, 151-159.

Asbury, A. C. and Hansen, P. J. (1987): Effects of susceptibility to endometritis and stage of cycle on phagocytic activity of uterine derived neutrophils. J. Reprod. Fertil. Suppl. 35, 311-316.

Castilho, L. F. F., Malschitzky, E., Gregory, R. M. and Mattos, R. C. (1994): Treatment of endometritis in the mare with homologous plasma containing neutrophils. Proceedings 6. International Symposium on Equine Reproduction, Caxambu, Brazil, 135-136.

Cheung, A. T., Liu, I. K. M., Walsh, E. M. and Miller, M. E. (1985): Phagocytic and killing capacities of uterine-derived polymorphonuclear leukocytes from mares resistant and susceptible to chronic endometritis. Am. J. Vet. Res. 46 (9), 1938-1940.

Dapino, P., Dallegri, F., Ottonello, L. and Sacchetti, C. (1994): Induction of neutrophil respiratory burst by tumour necrosis factor alpha; priming effect of solid-phase and intervention of CD11b/CD18 integrins. Clin. Exp. Immun. 94, 533-538.

Emmendörffer, A., Hecht, M., Lohmann-Matthes, M. L. and Roesler, J. (1994): A fast and easy method to determine the production of reactive oxygen intermediates by human and murine phagocytes using dihydrorhodamine 123. J. Immun. Met. 131, 269-275.

Evans, M. J., Hamer, J. M., Ganson, L. M., Graham, C. S., Asbury, A. C. and Irvine, C. G. H. (1986): Clearance of bacteria and non-antigenic markers following intra-uterine inoculation into maiden mares: effect of steroid hormone environment. Theriogenology 26, 37-50.
Hughes, J. P. and Loy, R. G. (1969): Investigations on the effect of intrauterine inoculation of Streptococcus zooepidemicus in the mare. Proc. Am. Assoc. Equine Pract., 289-292.

Kenney, R. M. (1978): Cyclic and pathological changes of the mare endometrium as detected by biopsy, with a note on early embryonic death. J. Am. Vet. Med. Ass. 172, 241-262.

Kydd, J. H., Antczak, D. F., Allen, W. R., Barbis, D., Butcher, G., Davis, W., Duffus, W. P. H., Edington, N., Grünig, G., Holmes, M. A., Lunn, D. P., McCulloch, J., O'Brien, A., Perryman, L. E., Tavernor, A., Williamson, S. and Zhang, C. (1991): Report of the first international workshop on equine leukocyte antigens, Cambridge, UK, July 1991. Vet. Immunol. Immunopathol. 42, 3-60.

Liu, I. K. M., Cheung, A. T. W., Walsh, E. M. and Ayin, S. (1986): The functional competence of uterine-derived polymorphonuclear neutrophils (PMN) from mares resistant and susceptible to chronic uterine infection: a sequential migration analysis. Biol. Reprod. 49, 507-514.

Mattos, R. C., Malschitzky, E., Mattos, R. and Gregory, R. M. (1997) Effects of different postbreeding treatments on fertility of thoroughbred mares. Pferdeheilkunde 13, 512-515.

Mitchell, G., Liu, I. K. M., Perryman, L. E., Stabenfeldt, G. H. and Hughes, J. P. (1982): Preferential production and secretion of immunoglobulins by the equine endometrium - a mucosal immune system. J. Reprod. Fertil. Suppl. 32, 161-168.

Naessens, J. and Hopkins, J. (1996): Introduction and summary of workshop findings. Vet. Immunol. Immunopath. 52, 213-235.

Pascoe, D. R. (1995): Effect of adding autologous plasma to an intrauterine antibiotic therapy after breeding on pregnancy rates in mares. Biol. Reprod. Mono 1, 539-543.

Peterson, F. B., McFeely, R. A. and David, J. S. E. (1969): Studies on the pathogenesis of endometritis in the mare. Proc. Am. Assoc. Equine Pract. 289-292.

Troedsson, M. H. T., Liu, I. K. M. and Thurmond, M. (1993): Function of uterine and blood-derived polymorphonuclear neutrophils in mares susceptible and resistant to chronic uterine infection: phagocytosis and chemotaxis. Biol. Reprod. 49, 507-514.

Watson, E. D. (1988): Uterine defense mechanisms in mares resistant and susceptible to persistent endometritis: a review. Equine Vet. J. 20, 397-400.

Watson, E. D., Stokes, C. R. and Bourne, F. J. (1987): Cellular and humoral defense mechanisms in mares susceptible and resistant to persistent endometritis. Vet. Immunol. Immunopathol. 16, 107-121.

Whicher, J. T. and Evans, S. W. (1990): Cytokine in desease. Clin. Chem. 36, 1269-1281.

Zerbe, H., Schuberth, H. J., Hoedemaker, M., Grunert, E. and Leibold, $W$. (1996): A new model system for endometritis: basic concept and characterization of phenotypic and functional properties of bovine uterine neutrophils. Theriogenology, 46, 1339-1356.

\section{Acknowledgements}

Gratitude is expressed to Dr. D. F. Antczak from the Equine Genetics Centre at the James A. Baker Institute for Animal Health of the Cornell University, Ithaca, New York for providing us with the indicated mAb from the equine monoclonal workshop.

\section{F. Engelke}

W. Leibold

Arbeitsgruppe Immunologie

H. Zerbe

Klinik für Geburtshilfe und Gynäkologie des Rindes

E. Klug

Klinik für Pferde

Tierärztliche Hochschule Hannover

Bischofsholer Damm 15

30173 Hannover

Tel.: $0511 / 8567241$

Fax.: 0511/856 7682 